ON

\title{
THE GELATINE OF THE BLOOD.
}

BY JOH N BOSTOCK, M. D.

or

LIVER POOI.

Reud Dec. 24, 1806.

Although different opinions have been entertained respecting the purposes which the blood server. in the animal œconomy, yet its obvious intluence over the functions of life, has, at all times, rendered it an important object of research, both to the phy: siologist, and the chemist. A complete investigation of its composition and properties is, however, attended with much difficulty: it is a fluid consisting of several ingredients, possessed of qualities peculiar to themselves, and existing in a state of combination, of which we have no other example. According to the latest and most accurate analysis of this fluid, it is supposed to consist of the following parts: fibrine, albumen, gelatine, red globules, spda, 
some neutral and earthy salts, a small portion of sulphur, and a peculiar phosphate of iron, all held in solution by a large quantity of water*.

The union of the fibrine and the red globules composes the basis of the crassamentuin or clot, which spóntaneously forms in the blood, shortly after its evacuation from the vessels. It is to the red globules that the iron is attached, and it seems probable, that from this metallic impregnation, their peculiar colour, and of course, that of the whole mass of blood is derived. The albumen, the jelly, and the different salts, all dissolved in water, constitute the serum. The characteristic property which the albumen possesses, of being concreted by heat, affords an easy method of obtaining it in a separate state; if, after being rendered insoluble by the process of coagulation, it be cut in suall pieces, and digested in water, The other ingredients of the serum will reinain suspended by the fluid, while the albumen itself is left behind in a state of considerable purity. By evaporating the vater we obtain the jelly, but it is unavoidably: mixed with the salts, from which it does not uppear possible entirely to separate it; this object can only: be in part accomplished, by a slow evaporation of

- Parmentier \& Deyeux, Jour. Phys. T. xliv. p. 43s, 9. Birlbeck re sanguine, tent. iuaug.

Tihompson's Ifourcroy, V. iii. p. 270, 3.

Fiourcroy, Système, T. ix. p. 110.

Thomson's Chemistry, iv. 585, \& seq.

Delanietherie, sur les etrés, \&c. T. ii. p. 149. 
the watary: it cinsequence of which, a portion of the salts, wilt assume their regular crystalline form, and may be thus removed from the mase. : The small quantity of sulphur whieh exists in the blood, appears to be united to the albumen; it has, however, never been obtained in a separate form, and its existence must be regarded as soniewhat problematical. That part of the serum, which remains fluid, after the albumen has been coagulated by heat, to which the name of jelly or gelatine has been. applied, is the last of the constituents of the blood, the presence of which bas been distinctly ascertained, and it is the one to which in the present paper I propose principally to direct my attention. .

In order to give a complete account of the subject, it will be necessary to review the different opinions that have been successively entertained respecting the constitution of the blood in general, the denominations that have been given to its different parts, and the state of relative combination in which they have been supposed to exist. In this review, I shall not entirely confine myself to those authors who have devoted their attention expressly to this subject; I shall notice the opinions of some writers who have only incidentally mentioned it, as from such sources we are often able to ascertain with equal correctness the progressive changes which take place in our knowledge upon topics of this description. After having accomplished this object, in as brief a manner as is consistent with accuracy, I ghall give 
manner as is consistent with accuracy, I shall give an account of some experiments that $I$ have performed on this part of the blood, which have induced me to adopt an opinion respecting it, different from that generally adopted.

We need not be long detained by the opinions of the ancients, on this subject; although they were frequently accurate in their descriptions of the phenomena of disease, and have manifested considerable diligence in anatomical investigations ; of chemistry they were intirely ignorant, and their physiology was so much perverted by pre-conceived hypothesis, as to havedeservedly fallen into complete neglect. According to the opinion of Galen, which, like the other opinions of this celebrated man, wasimplicitly adopted for some centuries, the blood consists of four parts: blood, properly so called, phlegm, bile, and black bile. Under the first denomination he appears to have included the compound of fibrine and red globules, which we call the crassamentum; the phlegm was used to designate the serum; and the title of black bile appears to have been given to the red globules at the lower part of the clot, which, in consequence of being secluded from the air, had acquired a dark hue. It is not easy to discover to which of the ingredients of the blood the name of bile was attached.*

* Galen, de elem. lib. 2. Harvey, de gen. Exer. 52. Willisii Opera, T. i. p. 66. Boerhaavii præl. ab Hallero, T. ii. p. 329. Castelli Lexicon, hæma, arrhichor, phlegma, \&c. 
The illustrious Harvey, who so successfully esta blished the true theory respecting the motion of the blood, appears to have been the first of the moderns who entertained any just conception of the nature of its composition. In his treatise on generation, published in the year 1651 , he distinctly speaks of its separation into fibrous and serous parts, as effected by the process of spontaneous coagulation. At the same time he describes a third substance, which occupies the higher part of the clot, and resembles jelly, mucilage, or albumen ovi, to which he gives the title of mucago, and which he regards as the part of the blood the most abounding with spirit. Some authors have supposed, that by this substance he meant to describe the buffy coat, which oceasionally appears on the surface of the blood, and others, the substance resembling cream, which sometimes floats on the serum, and was particularly attended to by Hewson and Hunter; but these opinions seem to be scarcely tenable, as this mucilaginous covering is described rather as a constant than as an accidental occurrence. Harvey is supposed to have been the discoverer of the property which the albumen possesses of being coagulated by heat *, and he says, that, by this process, the serum is converted into the peculiar mucilage described above. His claim is rested upon the following passage. -

- Haller, El. Phys. lib. v. sect. 3. \& 2. Thomson's Chem. v. iv. p. 587 . 
¿ Et quemadmodum, crudescente sanguine, parụw * admodum istiusmodi mucaginis sujpernatantis re" peritur; ita, si saniem illam a grumo separatam; " \& effusam leni foco decoxeris; eandem breví " in mucaginem hanc mutatam iri conspicies." “ Quippe urina coctione non densatur in fibrosum " mucaginem, sed potius in lixivium: aquosa au"t tem, sive saniosa hæc pars (sanguinis) aliquandiu a. leviter cocta, in mucaginem innatantem abit:-

It must be confessed, that this is not a very accurate description of the process, nor dues the term mucago seem at all applicable to the coagulated serum. We may perhaps explain the passage, by supposing, that the coagulation was imperfectly performed, in consequence of the heat either not being sufficiently raised, or not having been long enough applied.

- A more accurate idea of the coagulable nature of the serum was entertained by Lower, who, in bis treatise on the heart, published in 1669, describes the liquor pericardii as being similar to the blood, because by the application of heat, it was coagulated and converted into a white jelly $t$. The fact is mentioned in equally distinct terms by Willis, whose works were published shortly after his death, which took placejin 1675. He supposed the blood to con-

\footnotetext{
* Harveii Exer. lii. de gen. + Lower de corde, p. 6 .
} 


\section{SOF THE ÉCOOD:"}

fain spirits, sulphur (from which its red colour is derived), salts, earthy matters, and water; and after a good deal of whimsical hypothesis about the analogy of the blood; first to wine, and afterwards to milk, he notices its division into the red fibrous part, and the coagulated serum. If this latter, he informs us, be exposed to the heat of a fire, it is concreted like the white of the egg, and a coagulum is likewise thrown down from it, by the addition of an acid*.

A considerable advance in our knowledge respect: ing the nature of the crassamentum, was made by Malpighi. In his treatise on polypi of the heart, probably written between 1670 and 1680 , he com: bats the idea that was generally entertained, that they consisted of coagulated serum, and gives it as his opinion, that they are formed from the crassamentum of the blood. He informs us, that by repeitedly washing the clot, its colouring matter is entirely removed, and a white substance is left, which, when viewed through a microscope, exhibits a reticulated or fibrous structure, exactly resembling that of polypi. He supposes the buffy coat, (" pellea crusta") which occasionally appears on the top of the clot, to be formed of the same fibrous substancet.

The knowledge which Borelli possessed respecting the composition of the blood was still farther

- Willisii op. T. 1. p. 72. † Malpighi op. de polspo cordia. 
matured. The albumen and the cruor, the parts into which the blood spontaneously separates, he cons ceived were themselves compounded bodies, the albumen consisting of a substance coagulable by heat, exactly like the white of the egg, and a watery serum impregnated with salts, while the clat was supposed to consist of a very glutinous substance, united to a purple juice. By repeated washing, the clot is converted into white fibres or reticulated membranes, while the red matter is carried off by the water:.

The celebrated Boyle wrote his "Natural His? tory of the Blood," in 1683, two years after the publication of Borelli's work; hut althaugh a very elaborate performance, and of considerable length it cannot be said to haye added much to our know: ledge respecting the nature of the blood. The at? tention of the author is almoșt exclusively occupied with an account of the effects of different chemical re-agents upon it, and he relates a pumber of processes which he performed for the purpose of ob. taining, what be calls the spirit of the blood. Ha speaks of its division into the fibrous and serpus parts, and correctly notices the effects of heat, acids, alkalis, alcohol, and the oxymuriate of mercury, in coagulating the serum.

The chemical analygis of the animal fuids was of

- Borelli de Motu Anip. T. ii. prop. 132. 
this time, pursued with great ardour; but as fire was the principal agent employed, it is not to be supposed that much important information would be obtained. Juncker is supposed to have been the first who analyzed the blood by destructive distillation; he resolved it into "water, spirit, volatile salt, oil, and fixed oil :" "except the water, these were all new products formed during the process. It was about this period that Leeuwenhoek entered upon his laborious microscopal researches into the nature of animal fluids, and among other curious discoveries, detected the presence of the red globules of the blood. He first announced this discovery in a letter to the secretary of the Royal Society, dated August 15th, 1673. Although he appears afterwards to have gone into much unfounded speculation respecting the composition of these globules, their rexistence has been since amply confirmed, and the discovery must be considered as forming an important step in the progress of our knowledge. $\dagger$

It had been long known that the blood contains a saline impregnation; but the first attempt to ascertain the nature of the salts, appears to have been made by Gulielmini, who, by slowly evaporating serum upon glass, obtained them in a crystallized state, and was thus able to distinguish their figure; he acknowledges that this method was first pointed out to him by Malpighi $\ddagger$. Gulielmini also paid a

* Junckeri Chymia, p. 75. † Phil. Trans. for 1674, p. 23.
$\ddagger$ Gulielmini Opera. T. ii. sect. 44. 
good deal of attention to the coagulable lymph, to which he gave the name of "fibra sanguinis." $\mathrm{He}$ wrote his Treatise on the Blood in 1 701. Lancisi's learned Dissertation on the Motion of the Heart and Arteries, was also written early in the 18th century, and contains many observations on the nature of the blood. He directed his attention particularly to the red globules, and controverted the hypothesis of Leeuwenhoek, who conceived that each globule was composed of a series of smaller globules. *

The constitution of the blood formed a very important part of the theory of the celebrated Boermaave, and he consequently paid much attention to its nature and properties; yet it does not appear that he materially added to the knowledge which was previously acquired upon the subject, and indeed, in some particulars, he seems to have had less accurate ideas respecting it than his contemporaries. Leeuwenhoek's hypothesis of the progressive series of globules, was adopted by Boerhaave in its fullest extent, and formed a fundamental part of his pathological doctrines. From some passages in his writings it may be inferred, that he did not consider the serous and fibrous parts of the blood as essentially distinct from each other, nor from the red globules, but that they all consisted of the same matter differently arranged, and he even speaks of the different parts as being converted occasionally into each

* Lancisi Opera. T.iv. de motu cord. post xvi. 
other *. Boerhaave entered upon the discussion of the question, which was at one time much agitated, whether the blood was acid or alkaline, and from finding that no effervescence was produced by the addition of either acids or alkalies to it, he concluded that it possessed neither of these qualities $t$. It is, however, now known that this conclusion was erroneous, and we are able to perceive the source of the error into which he was betrayed.

We may notice the account that Hoffman gives of the blood, rather in consideration of his general celebrity, than from any peculiar sagacity which he displayed upon this subject. Blood, he supposes, is composed of watery, sulphureous, and earthy parts ; that it is nothing more than a purple jelly, although it differs from common jelly in being more inflammable, in yielding more volatile salt and oil when distilled, and in being more fotid when it putrifies. He concludes therefore that blood is a jelly of a more concocted or subtile kind. $\ddagger$

The next account of the blood that we meet with is in Senac's elaborate Dissertation on the Heart. He describes in detail its different constituents, with considerable minuteness; beginning with the red globules, he afterwards proceeds to what he calls $\&$ not.

* Boerhaave, aphor. sect. 93, 94. — prælect. sect. 223.

+ Boerhaave, chem. T. ii. proc. II4.

† Hoffman, Rat. Med. lib. i. seet. I. cap. 5 . 
the lymph, then the gelatinous matter, the mucus, and lastly the serosity. By lymph he certainly meant to designate the part which we now call fibrine; he, however, appears to have had no very accurate conception of the difference between the fibrine and the albumen, as he says the lymph may be hardened by exposure to heat; and he also supposes that the buffy coat of inflamed blood is composed of albumen. With respect to the jelly and the mucus said to be in the blood, he seems rather to have inferred their existence from analogy, than to have actually detected their presence. He compares the jelly of the blood to that which is found in broth, and says that it may be obtained from the blood by boiling it. The existence of mucus he infers, from the quantity of this substance which is poured out on the secreting surfaces with which the body abounds; conceiving it more probable that it should have been ready formed in the blood, than generated by glands lying contiguous to the parts. By the serosity Senac unquestionably meant the serum; he says it is coagulated by heat, and resembles the white of the egg; and he points out the particulars in which it differs from jelly*. As far as I have been able to collect, Senac is the first writer who employed the words coagulable lymph and serosity; he used the first in the same sense in which we now employ it; but he certainly considered serosity as synonimous with serum, and he does not appear to have had any

* Senac, traité du cœur, liv. 3. chap. 4 . 
idea of the existence of that part of the blood to which some late writers have applied the term.

Not long after Senac, De Haen published some remarks upon the blood. He points out the method of obtaining the fibrine, or as he styles it, the mem. brane of the blood, by rapidly stirring it, when fresh drawn, with a stick (a process which he informs us was first practised by Ruysch) or still more readily, by agitating the blood in a bottle. After noticing the resemblance of the serum to the white of the egg; he informs us, that if blood be suffered to flow into warm water, a substance is procured from it which he calls "gelatum." This was probably a thin film of coagulated fibrine; it certainly could not have been what has since been called the jelly of the blood.

As M. Fourcroy refers to De Haen, as the original observer of the gelatine, I shall quote at length the passage in which he describes this peculiar sub. stance.

“Sanguinem alium ex brachio, alium ex pede " effluentem, in aquam ad 100 gradus thermometro " imposito calentem, excepi. Sanguis ille obser. " vatur primo hanc aquam æquabili rubedine tin" gere, si jactus ejus citatus est : refrigeratæ dein “ aquæ innatat plurimum albescentis pellucidi, glu" tinosi, fugientis ad tactum, manu, aut cochleare " vix capiundi; hæc si brevi à venæ sectione rem " explores. Si vero per 8, 10 horas aqua illa post 
is venw sectionem sine examine reponatur, revoce" turque ad examen, habebit nonnunquam parum " illius pellụcidi glutinosi, sed multo solidius, colore is fuscum, facilius capiendum. Hoc contentum qua c scirem quid esset, pluries illud charta emporetica, " linteo suffulta, percolavi: nonnunquam remansit is nihil; aliquoties quid pauci, glutinosi, quod exse siccatum furfura, griseive pulveris instar, in cs spiritu vini perstitit. Materies hæc glutinosa, ex “ aqua adhuc calente, mox a venæ sectione excepta, " \& vel ramulo, aut lagenæ, agitata, iteratis expe"rimentis nihil unquam dedit membranosi. Si exis perimentum instituis longè post venæ sectionem, is ubi aliquoties contenta materies solidior apparet, cest tamen idem experimenti effectus. Hæc porro "s solidior materies, ab ea, quæ ex calente adhuc "aqua eximitur, differt in eo, quod percolata * plus relinquat materiæ glutinosæ fuscæ. Hanc "superstitem a percolatione materiem per horam agitavi lagena, visuru's num membranam daret? "Nequaquam; agitatio illa materiem modo ex fusco " reddidit rubicundiorem. Percolata omnium ho" rüm experimentorum aqua rubella est, \& mucosi "quid in fundo habet. Bidui spatio omne id mu" cosum fere evanescit in aqua. Experịinenta hæc " scepius, \& in phlogistico sanguine, \& in sano, capta - sunt. Gelatum ergo illud, quod in aqua calida "- a-misso sanguine colligitur, neque materies factitia - membranæ est, ut mox ostendi, neque etiam est es crustæ phlogisticæ materia. Est enim gelatum * hoc in quavis aqua, in quam calentem sanguis 
" sive ex brachio, influxerit. Saltem si esset crusta

" materies, ii, quibus neque a morbo, neque a "Gravitate, neque a diathesi, crusta adesset, gelati " carerent." "

Our knowledge respecting the blood was in this state, when in the year 1759, the celebrated Haller published the second volume of his Elements of Physiology, in which he treats with considerable minuteness, of the nature and properties of the blood. He details the opinions of many of his predecessors, and discusses the various controverted points with much of his accustomed candor and learning. We cannot, however, but remark, that this illustrious physiologist entertained less correct notions abaut the blood, than might have been expected from one possessed of his extensive information and indefatigable research. After noticing the separation into crassamentum, or as he calls it, cruor, and serum, and describing the former of these substances, he devotes a section to the particular examination of the latter. He supposes that it consists of water, mucus, and jelly; but it appears evident from several parts of his work, that he did not employ the term jelly in that confined sense to which it is restricted by the accuracy of modern chemistry. He seems not to bave been aware of the distinction which exists between the albumen of the blood, and the jelly which is obtained by boiling the membra-

- De Hzen, Rat. Med. pars 1. cap. 6. 
nous parts of animals; he also confounds it with the exsudation which proceeds from wounded vessels, and which closes up the mouths of arteries, and he even imagined that polypous concretions, and the buffy coat of inflamed blood are formed of albumen. Hence we may safely conclude, that, although he enumerates jelly among the constituents of the serum, he was not acquainted with the substance to which the term gelatine has been since applied by Fourcroy and other later writers; there is no evidence of his having obtained it in a separate state, or even hav. ing been aware of its existence, and he evidently uses the word jelly to describe a substance of very different properties. By the mucus of the blood Haller meant to speak of that substance which was obtained by De Haen, by permitting the blood to flow into warm water; for the proof of its existence he refers to the passage which I have quoted above from this author. I do not find that the word serosity is mentioned by Haller in his Elements of Phy. siology.*

From the account which I have given of the authors who have treated of the subject before this period, we may conclude, that the existence of any animal matter in the serum, uistinct from the albumen, and not coagulable by heat, was unknown to them; much less was there any idea entertained of the serum containing a proper jelly. When this

* Haller, El. Phys. lib. 5. sect. 3. 
word was employed by these writers, to designate any of the constituents of the blood, they used it in a vague sense, generally applying it to the serum, but sometimes to the whole mass of the blood. We may remark that the word jellying, or some synonymous term, is frequently employed to describe the process of coagulation, both the spontaneous concretion of the crassamentum, which takes place when blood is drawn from the vessels, and the consolidation of the albumen, which is effected by heat. Of this we have the most striking illustration in the works of Haller himself, who entitles one of his sections, "Seri pars quæ cogitur, vel gelatinosa."

The publication of Haller's great work may justly be considered as forming an important æra in the history of the science; by rendering information more accessible, it tended materially to the diffusion of physiological knowledge, and thus immediately prepared the way for many important improvements. After having ascertained the state of the opinion that was entertained respecting the serum of blood at this period, I shall now proceed to trace the different changes which it bas undergone until the present day.

The first clear notification which I have met with of an uncoagulable animal matter in the serum, is in an inaugural dissertation published at Edinburgh in 1760 , by Dr. Butt. After remarking the separation of the blood into serum and crassamentum, he observes, 
that serum consists of two parts, a coagulable substance, and a watery fluig; which last also exhibits marks of containing some animal matter. Dr. Butt fell into the inaccuracy, which was common among his contemporaries, of considering the albumen and coagulable lymph not to be essentially different from each other; he expressly states, that he regards the white of the egg as nothing more than coagulable lymph in its purest form*. No notice is taken of this peculiar part of the serum by Gaubius, who published his pathology in 1763; indeed he so little understood the nature of this fluid, as to conclude that its glutinous texture depended upon a mucilaginous matter, resembling vegetable gum $t$.

.It was three years after this period, that the celebrated Cullen first gave medical lectures at Edinburgh, and I believe, it was about the same time, that be published, for the use of his class, the text book entitled "Institutions of Medicine," in which we may observe some farther advances in our knowledge respecting the constitution of the blood, although the account which he gives is still embarrassed with much inaccuracy. What had been called the fibrous part of the blood by Malpighi, Gulielmini, Gaubius, and others, and by Senac the coagulable lymph, Cullen denominated gluten. He observes, that when the serum has been coagulated

- Butt, p. 53. \& alibi.

+ Gaubii Inat. path. sect. 337, \& seq. 
by heat, if it be cut into small pieces, a thin fluid, of a saline taste, exudes from it; to this fluid he gave the name of serosity, and he considered the serum as formed merely by the solution of a quantity of gluten in this serosity *. Hence it appears, that he had not a distinct conception of the difference between the albumen and the gluten, nor of their relation to each other. We may remark also, that the sense in which he employed the word serosity, was very different from that given to it by its original inventor Senac; yet the wide diffusion which the opinions of Cullen would acquire, in consequence of his situation as a public teacher, necessarily gave them a great degree of currency, and we accordingly find that, from this period, the word serosity was generally restricted to the uncoagulable part of the serum.

In the year 1770, Mr. Hewson first published the result of his inquiries into the nature and constitution of the blood; some of his opinions, particularly those respecting the red particles, are now discarded, as being without foundation, but on many points he will be found to be considerably more correct than aly of his predecessors. After remarking that the cuagulable lymph and serum had been confounded with each other, even by the best informed writers, inmediately preceding the period when he wrote, he proceeds to notice their distinctive characters, and

* Cullen's Instit. of Med. sect. 247. \& seq. 
after describing the coagulation of the latter substance, observes that a watery fluid may be pressed out of it, which he calls the serosity. This fluid, he says, contains the neutral salts of the blood, and also a mucilage which cannot be coagulated by heat; but if part of the water be evaporated, it then acquires a firm consistence, and resembles the mucus spit up from the lungs, when dried*. Mr. Hewson has indeed fallen into an error, in supposing that this peculiar fluid has the name of serosity given to it by Senac; this author, as we remarked above, seems to have been the first who used the word, but he applied it to the serum at large, while Cullen restricted it to this particular part of it. Gaber, who performed his experiments on pus about the time of Mr. Hewson's publication, and who imagines that purulent matter was formed from what he calls serosity, evidently iutended, under this denomination, to speak of the serum at larget. Dr. Gregory, on the other hand, in his "Conspectus," uses the word serosity in the same sense with Cullen $\ddagger$. I do not find that this part of the blood is noticed by Mr. Hey in his “ Inquiry."

No particular alteration appears to have taken place in the opinions respecting the composition of the blood until the year 1790, when the following

* Phil. Trans. 1770; \& Inquiry, passim. + Journ. de Phys. Introd. T. ii. p. 29. † Gregory, Conspect. T. i. sect. 502. 
discovery was announced to the academy of sciences by M. M. Fourcroy and Vauquelin. "If serum be " exposed to heat, after being mixcd with half its " weight of water, it is in part coagulated, and the "portion of liquid which is not coagulated coutains "gelatine, which gelatinizes by cooling*." The discovery was developed more at large in a future paper, in which the authors inform us, that a slightly turbid fluid may be separated from coagulated albu. men, which by evaporation and cooling, concretes into a substance possessing every characteristic of true jellyt. They state that this substance had been seen by De Haen, though without referring to any particular part of his treatise; but from a careful perusal of it, in conncction with the references made to it by Senac and Haller, I believe there can be no doubt, that it is the passage which I have quoted above that contains the supposed discovery of De Haen. I have already stated, that I am dis. posed to draw a different conclusion from it.

A still more particular account of this substance is contained in a paper published by M. M. Parmentier and Deyeux in 1794. They appear at first to have entertained some doubt about the accuracy of M. Fourcroy's conclusion, and took considerable pains to ascertain the properties of this sup-

- Ann. de Chimie, T. vi. p. 182.

+ Mem. Acad. Scien. 1789, p. 297.

Ann. de Chimie. T. vii. p. 146. 
posed gelatine. Their experiments led them to bo fully satisfied as to its existence, and they relate with minuteness, both the process which they employed to procure it, and the nature of the substance which they obtained. 'The properties, however, which they ascribe to it are neither essential to, nor characteristic of, jelly. They do not state that it is capable of being concreted by cold, nor do they notice the effects of any decisive chemical tests; they inform us that it is glutinous to the touch, and that when dried, it composes a hard transparent film*.

At the same time that the French chemists were thus occupying themselves with detecting the properties of this ingredient in the blood, the celebrated John Hunter, ignorant probably of their operations, was likewise engaged in examining the same substance. He describes the serum of the blood as consisting of two distinct fluids, one coagulable by heat, like the white of the egg, and the other, which remains uncoagulated. He discovered that this peculiar part of the serum is precipitated by Goulard's extract, and in this manner he attempted to ascertain the relative proportion in which this substance and the albumen of the blood existed in the blood of different individuals, and in other serous fluids which he examined. This method, however, as will afterwards appear, is totally inadequate to the purpose. None of the properties of this substance, as

? Journ. de Phys. T. xliv. p. 438, .9. 
pointed out by Mr. Hunter, are at all analogous to those of jelly, nor does it appear that he, in any respect, considered it as a gelatinous fluid.*

Since this period no material change seems to have taken place in the opinion entertained respecting the constitution of the blood, at least with regard to the existence and properties of the gelatine. Those writers who have treated the subject the most copiously, Dr. Birkbeck $\dagger$, Mr. Allen $\ddagger$, M. Dumas ॥

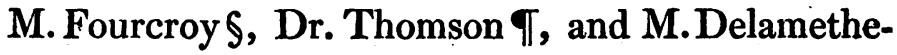

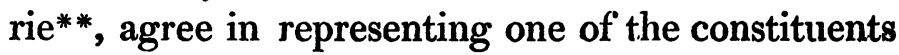
of the blood to be a proper jelly, which is liquefied by heat, and congeals again by cooling, and the same opinion is maintained by Professor. Blumenbach $+t$,

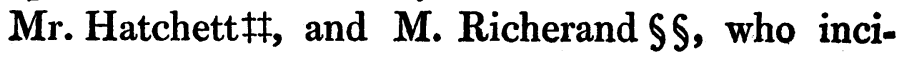
dentally mention the subject. The only author of respectability, who supports a different doctrine, is Mr. John Bell ; but I conceive, that a perusal of his remarks on the blood will prove, that notwithstanding his acknowledged talents, and the acuteness with which he has detected the mistakes of others, he

\footnotetext{
* Hunter on the Blood, p. 32, 3 .

+ Tent. Inaug. de sanguine, passim.

$\ddagger$ Thomson's Fourcroy, T. iii. p. 270-3.

|| Dumas, Princip. de Phys. T. ii. p. $37,8$.

\$ Fourcroy, Systeme, T. ix. p. 140.

Iा System of Chemistry, V. iv. p. $585 . \&$ seq.

** Delametherie, Considerations, T. ii. p. 148.

† + Blumenbach, Inst. Phys. sect. 11 .
}

$\ddagger \ddagger$ Phil.Trans. 1800. p.40I. $\oint \oint$ Richerand, Elem. Phys. p. 184. 
has himself, on this subject, betrayed a great deficiency of information. He says that blood cqnsists of crassamentum, serum, and red globules, forgetting that the red globules are one of the component parts of the crassamentum; he uses the terms gluten and jelly as synonimous, and expressly states, that all attempts to distinguish between the glutinous and albumenous parts of the blood are vain and useless. Although he frequently employs the word jelly, when speaking of the constituents of the blood, it does not appear that he had any distinct conception of that part of the serum which we are now describing; indeed the whole section is so confused, that it is not easy to develope the author's exact meaning*.

Having thus completed a sketch of the opinions that have been entertained by others upon the subject, it remains for me to give an account of my own, and especially to point out the circumstances in which they differ from those of my contemporaries. Before, however, I can do this, I shall be under the necessity of adverting to some experiments that I have lately made on the analysis of animal fluids, and on the method of discriminating between those which the most nearly resemble each other in their visible properties, and which, in consequence of their being found in greater or less proportion in almost all parts of the body, I have denominated primary. Of these there are three, albumen, jelly, 
and mucus. The distinguishing characters of the first are its being cuagulable by heat, and by the oxymuriate of mercury. The second is liquefied by heat, and becomes solid again by cold, it is not affected by the oxymuriate of mercury, but is precipitated from its solution by tan; while mucus is neither coagulated by heat, nor has the power of concreting by cold, it is not affected by the oxymuriate of mercury, nor by tan, but it is copiously precipitated by the acetate of lead*.

In order to ascertain the nature of the uncoagulable part of the serum, I exposed a quantity of it for some time to the beat of boiling water; it concreted, in the usual manner, into a solid mass, but upon being divided into small pieces, and laid upon an inclined pane of glass, a brownish liquor oozed from it. The pieces of serum were afterwards digested in boiling water, which became tinged of a brown colour, owing to some substance previously contained in the serum which it had carried off. The fluid which oozed from the coagulated serum, and the water in which it had been digested, were added together. To a portion of it a small quantity of the solution of the oxymuriate of mercury being added, it became milky, and a precipitate was formed; it was also rendered opake by being for some time exposed to the boiling temperature.

* Ed. Med. Journ. V. i. p. 257. Nicholson's Journ. V. xi, p. 244. 
Hence I found that it still contained some uncoagulated albumen, and in order more effectually to separate it, I diluted a quantity of serum with six times its bulk of water; to this I added the solution of the oxymuriate of mercury, until no farther precipitation could be perceived, and placed the compound in the water bath. The coagulum was by this process rendered considerably firmer than when heat only had been employed, and the liquor remained nearly transparent; it was passed through a filtre, and now no precipitate could be obtained by the addition of the infusion of tan. A quantity of the water in which coagulated serum had been digested was slowly evaporated; when the greatest part of the water was separated, it was suffered to cool, but no appearance of gelatinization was perceptible. The evaporation was then continued to dryness; a tenacious film of animal matter was left behind, which did not in any respect resemble dried jelly, and which was with difficulty re-dissolved by the addition of more water. These experiments were several times repeated, and the results were essentially the same, so far at least as affected the conclusion to be drawn from them. It is necessary, however, to remark, that in trying different speciunens of serum, there was a considerable difference perceptible in the readiness with which the albumen was separated fiom the uncoagulable part; in some instances a single operation was sufficient, while in others it was necessary to repeat the addition of the oxymuriate of mercury and the boiling four or five 
times, until the liquor which passed through tho filtre was entirely freed from the uncoagulated albumen.

From these experiments I felt myself justified in concluding:-First, That when diluted serum is completely deprived of albumen, which is proved by its no longer yielding a precipitate, upun being boiled with the oxymuriate of mercury, it is not affected by the infusion of tan. Secondly, That the animal matter contained in serum, which is not coagulated by the operation of heat or the oxymuriate of mercury, does not possess the property of concreting by cold. Whence we may infer, in the third place, That that part of the serum which is not coagulable by heat does not possess the properties which are essential to jelly, either physical or chemical.

Having thus found that the uncoagulable part of the serum is not jelly, I was induced from my ideas of the constitution of animal fluids, to consider it as consisting of mucus. I have not indeed been able unequivocally to establish this opinion, for although the water in which the albumen had been digested, was very copiously precipitated by the acetate of lead, yct it might be conceived that t!lis effect was produced by the decomposition of the different saline bodies that exist in the blood. I however, thought myself authorized in considering it to be a proper mucus, both from the nature of che precipitate produced by the acetate of lead, which ex- 
hibited the peculiar flaky form, which is indicative of an animal or vegetable impregnation, and likewise from observing the appearance that it assumed by evaporation. Before I leave this part of the subject I may observe, as a confirmation of the inferences deduced from my experiments on serum, that I have had an opportunity of examining the fluids from a tumor on a diseased spine, from a case of hydrocephalus internus, and from a hydrocele, and that $I$ could not in any of them detect the least trace of jelly.

As the opinion which is entertained, by authors of the first respectability, respecting the uncoagulable part of the serum, appears to be incorrect, it may be thought incumbent upon me to point out the circumstances which have contributed to establish the erroneous doctrine. In the first place we may observe, that a considerable degree of inaccuracy pervades the language of even the most correct writers on subjects connected with animal chemistry. The terms jellying or gelatinization, which ought to be restricted to the property that heated jelly possesses of becoming solid by cold, have been applied to every case in which a fluid substance is converted into the concrete state; whether by heat, as in the instance of the albumen, or by what has been called spontaneous coagulation, as is observed in the fibrine. This inaccuracy may probably, in the first instance, have misled M. Fourcroy, who finding these expressions employed by writers of high reputation, a 
applied to the constituents of the blood, entered upon his experiments with his mind biassed in favour of the idea, that be must meet with jelly as one of its component parts. When, under this impression, he instituted his experiments upon the uncoagulable part of the serum, it is easy to conceive, that he might mistake the effects of desiccation for those of gelatinization, and as far as appears, he did not employ any other method of ascertaining the nature of the substance, than the change produced in it by the effect of heat. Indeed, although be states the fact in different parts of his works with perfect confidence, and claims the discovery, as one which he thought of importance, he no where gives us any account of the manner in which his cxperiments were conducted. The subject was treated much more in detail by M. M. Parmentier and Deyeux, but although they conclude in favour of M. Fourcroy's opinion, we shall not find that their results authorise this conclusion. They do not say that the substance which they obtained concreted by cold, nor do they seem to have thought of examining its nature by any chemical tests; the properties which they point out are by no means characteristic of jelly.

As to Mr. Hunter's experiments, it is obvious that they rather confirm, than oppose, the opinion that $I$ an desirous of establishing. He found the part of the serum, which is not coagulable by heat, to be precipitable by the acetate of lead, a substance, 
which is the appropriate test of mucus, and has no action upon jelly. He does not appear to have examined the effects of beat upon it. The authors who have more recently treated upon the subject appear, at least for the most part, to have taken up the opinion of the French chemists without farther examination; and indeed, after the very direct manner in which it had been stated, we can scarcely accuse them of rashness or improper confidence. Both Dr. Birkbeck and Mr. Allen, however, mention the effect of $\tan$ in throwing down a copious precipitate from the serosity, but from the way in which it was obtained, by pressing it from serum that had been exposed to heat, we must conclude, that it still contained a pcrtion of uncoagulated albumen, which would be acted upon by the tan. Thus it appears that the erroneous opinion, which these gentlemen derived, in the first instance, from the French chemists, was confirmed by the circumstance of their operating upon the substance in an impure state. 